\title{
The synovial membrane in osteoarthritis: a histological study including the characterisation of the cellular infiltrate present in inflammatory osteoarthritis using monoclonal antibodies
}

\author{
PETER A REVELL, VIVIEN MAYSTON, PEGGY LALOR, AND PAUL MAPP \\ From the Department of Morbid Anatomy and Bone and Joint Research Unit, The London Hospital Medical \\ College, London
}

SUMMARY Inflammatory infiltration of the synovial membrane has been described in a proportion of cases of osteoarthritis (OA). Using conventional histology, lymphoid follicles, diffuse fibrosis, and perivascular fibrosis were shown to be present to a significantly greater extent and in more synovial membranes in osteoarthritis than in those cases where there was a mechanical or traumatic background to the joint disease. Calcium pyrophosphate dihydrate crystals (five patients) and detritic fragments of bone and cartilage (seven patients) were present in small numbers of the total cases of OA (38) studied. Neither of these features was related to the presence of an inflammatory infiltrate. Examination of 20 osteoarthritic synovial membranes using monoclonal antibodies showed the presence of lymphoid follicles containing $\mathrm{T}$ helper and $\mathrm{T}$ suppressor lymphocytes, B lymphocytes, and macrophages expressing HLA-DR in five cases. The $T$ helper:suppressor ratio varied between $1: 1$ and $2 \cdot 5: 1$ in these follicles. In addition, half of the OA samples, including these five cases, showed the presence of a diffuse cellular infiltrate containing $\mathrm{T}$ and $\mathrm{B}$ lymphocytes and macrophages, which were HLA-DR positive. Granulocytes were present in this diffuse infiltrate in those cases containing lymphoid follicles. The results confirm the presence of an inflammatory form of osteoarthritis but also show that the proportions of lymphoid cells are not the same as those considered to be typical of rheumatoid arthritis.

Key words: lymphocytes, macrophages, inflammation.

The synovial membrane in osteoarthritis (OA) shows a more or less 'normal' appearance with no increase in the thickness of the intimal cell layer or significant cellular reaction according to early accounts. ${ }^{1} 2$ The presence of a low grade chronic synovitis in a proportion of cases has been suggested recently, ${ }^{3-5}$ and in one study some $O A$ synovial membranes showed changes comparable with those of rheumatoid arthritis (RA). As osteoarthritis is generally considered not to be an inflammatory condition and because OA synovial membrane has been used to provide non-inflamed control material for comparative purposes in studies of the inflamed

Accepted for publication 10 September 1987.

Correspondence to Dr Peter A Revell, Bone and Joint Research Unit, The London Hospital Medical College, Whitechapel, London E1 2AD. rheumatoid synovial membrane $e^{6-10}$ we decided to examine the histological appearance of the synovium in osteoarthritis using conventional staining methods and to type any inflammatory cells present using monoclonal antibodies (MAbs). Synovial membranes from patients with a history of trauma or mechanical joint derangement were used for comparison.

\section{Materials and methods}

Thirty eight samples of synovial membrane were obtained from patients with osteoarthritis together with 29 samples from patients with a mechanical or traumatic (MT) background to their joint problem. Table 1 outlines the clinical details of the patients. The mean duration of involvement in the joint from 
Table 1 Clinical details of patients studied

\begin{tabular}{|c|c|c|c|c|c|}
\hline \multirow[t]{2}{*}{ Diagnosis } & \multirow[t]{2}{*}{ Sex } & \multirow{2}{*}{$\begin{array}{l}\text { Number } \\
\text { of cases }\end{array}$} & \multicolumn{2}{|l|}{ Age (years) } & \multirow{2}{*}{$\begin{array}{l}\text { Joints } \\
\text { examined }\end{array}$} \\
\hline & & & Mean (SD) & Range & \\
\hline Ostcoarthritis & $\begin{array}{l}\mathrm{M} \\
\mathrm{F}\end{array}$ & $\begin{array}{l}13 \\
25\end{array}$ & $\begin{array}{ll}52 \cdot 5 & (13 \cdot 6) \\
6(0 \cdot() & (15 \cdot 8)\end{array}$ & $\begin{array}{l}37-80 \\
45-87\end{array}$ & $\begin{array}{l}9 \text { knec. } 4 \text { hip } \\
13 \text { knec. } 12 \text { hip }\end{array}$ \\
\hline Mechanical or traumatic & $\begin{array}{l}\mathrm{M} \\
\mathrm{F}\end{array}$ & $\begin{array}{l}16 \\
13\end{array}$ & $\begin{array}{l}26.7(10.3) \\
38.2(17.3)\end{array}$ & $\begin{array}{l}17-49 \\
15-76\end{array}$ & $\begin{array}{l}14 \text { knec. } 2 \text { hip } \\
11 \text { knee. } 2 \text { hip }\end{array}$ \\
\hline
\end{tabular}

which tissue was obtained was 111 months (range 12-480) for the OA cases and 18 months (range 3-60) for the MT cases. Six of the patients with OA had single joint involvement, 28 had less than four joints affected, and four had involvement of many joints. Thirty five of the OA samples were obtained at the time of surgery, the remaining three at arthroscopy. Nine of the MT samples were obtained at surgery, the remainder comprising three needle and 17 arthroscopic biopsy specimens. None of the cases had clinical evidence of an inflammatory joint disease. Tissue was fixed in $10 \%$ formal saline and processed on an automatic tissue processor, embedded in paraffin wax, and sectioned at $5 \mu \mathrm{m}$ thickness before staining with haematoxylin and eosin.

Fresh samples of tissue were available in 20 of the OA and six of the MT cases, and these were frozen in liquid nitrogen-isopentane before cryostat sections $(7 \mu \mathrm{m}$ thickness) were prepared for staining with MAbs in an indirect immunoperoxidase system. Table 2 shows the specificities of the MAbs. There were HLA-DR molecule, monocyte/ macrophage, $\mathrm{T}$ helper and $\mathrm{T}$ suppressor lymphocyte, Pan B lymphocyte, and granulocyte markers. Frozen sections were air dried overnight, fixed

Table 2 Monoclonal antibodies (MAbs) used to identify cells in the synovial membrane

\begin{tabular}{lll}
\hline$M A b$ & Target cell & Reference \\
\hline 24 & $\begin{array}{l}\text { Macrophages } \\
\text { (includes 50\% monocytes) } \\
\text { Macrophages, neutrophils } \\
\text { (receptor for C3bi component of } \\
\text { complement) }\end{array}$ & 20 \\
$\quad \begin{array}{l}\text { Macrophages, neutrophils } \\
\text { (receptor for C3bi component of }\end{array}$ & 21 \\
OKM1 & $\begin{array}{l}\text { complement } \\
\text { Macrophages } \\
\text { (high affinity Fc receptor) }\end{array}$ & 22 \\
OKT4 & $\begin{array}{l}\text { T helper cells } \\
\text { OKT8 }\end{array} \quad \begin{array}{l}\text { T suppressor cells } \\
\text { Pan B }\end{array} \quad \begin{array}{l}\text { B lymphocytes } \\
\text { H2 }\end{array} \quad \begin{array}{l}\text { Ortho } \\
29\end{array} \quad \begin{array}{l}\text { Granulocytes } \\
\text { Ortho }\end{array}$ \\
\hline
\end{tabular}

in fresh acetone at room temperature for 10 minutes, incubated with $25 \mu \mathrm{l}$ of MAbs for 30 minutes, washed three times in trometamol (TRIS) buffered saline (TBS) followed by peroxidase conjugated rabbit antimouse immunoglobulin (Dako 1:30), then further washed three times in TBS. A positive reaction was shown by a seven minute incubation in diaminobenzidine $(0.5 \mathrm{mg} / \mathrm{ml})$ containing hydrogen peroxide $(0 \cdot 01 \%)$.

All histological sections were examined without knowledge of the clinical details of the case, including the diagnosis. Haematoxylin and eosin sections were scored semiquantitatively for the presence of intimal cell hyperplasia, fibrin deposition, iron, diffuse lymphocytic infiltrate, lymphoid follicles, plasma cells, diffuse fibrosis, perivascular fibrosis, increased vascularity (capillary and noncapillary), and perivascular lymphocytes. A simple scoring system was adopted $(-$, feature absent; \pm , feature minimal, not readily apparent but present; + , feature easily recognised or even prominent). In addition, the presence or absence of detritic cartilage, bone fragments, and crystals was noted. Sections stained with monoclonal antibodies were scored for the presence of positively staining cells using a similar semiquantitative system, with note also being taken of the localisation of cells in the synovial membrane. Statistically significant differences between the groups of OA and MT synovial membranes were sought using the $\chi^{2}$ test.

\section{Results}

HISTOLOGICAL FEATURES OF

OSTEOARTHRITICAND MECHANICAL/

TRAUMATIC SYNOVIAL MEMBRANES

The OA synovial membranes were significantly different from those of the MT cases with respect only to the presence of lymphoid aggregates, diffuse fibrosis, and perivascular fibrosis when the numbers of samples showing different semiquantitative gradings for each of the histological features were compared using conventional staining and differences sought by the $\chi^{2}$ test. Table 3 shows the 
Table 3 Histological features which were present significantly more often in osteoarthritis $(O A)$ than in mechanical/traumatic $(M / T)$ synovitis

\begin{tabular}{cllll}
\hline & & $\begin{array}{l}\text { Feature } \\
\text { absent } \\
(-)\end{array}$ & $\begin{array}{l}\text { Feature } \\
\text { minimal, } \\
\text { but present } \\
( \pm)\end{array}$ & $\begin{array}{l}\text { Easily recognised } \\
\text { or prominent } \\
\text { feature } \\
(+)\end{array}$ \\
\hline $\begin{array}{c}\text { Lymphoid } \\
\text { aggregates }\end{array}$ & OA 21 & 10 & 7 \\
& MT 25 & 4 & 0 \\
& $\chi^{2}=8 \cdot 84 ; \mathrm{p}<0.01$ & \\
Fibrosis & OA 6 & 22 & 10 \\
& MT 16 & 11 & 2 \\
Perivascular & $\chi^{2}=19 \cdot 63 ; \mathrm{p}<0 \cdot 01$ & \\
fibrosis & OA 17 & 13 & 8 \\
& MT 24 & 4 & 1 \\
& $\chi^{2}=10 \cdot 51 ; \mathrm{p}<0.01$ & \\
\hline
\end{tabular}

relevant statistically significant results for these particular features. All three features were present to a greater extent in the OA than in the MT synovial membranes. No other histological differences were seen between the two groups. All the features were absent or present in both groups to a variable extent. Seventeen cases of OA showed the presence of aggregates of lymphoid cells compared with only four MT cases, and in none of the latter were such collections a well developed feature, whereas in seven of the OA cases there were well formed lymphoid follicles. A diffuse lymphocytic infiltrate was present in $20 \mathrm{OA}$ samples, though this was not a prominent feature (scored \pm ) in 12 of these, and the diffuse lymphocytic infiltration was not statistically different overall from that seen in the MT cases.
Crystals of calcium pyrophosphate dihydrate (CPPD) were present in five of the OA synovial membranes, and a further seven samples showed the presence of detritic fragments of bone or cartilage, or both. None of the OA synovial membranes contained both detritus and CPPD crystals. Differences in the individual histological features were sought between these subgroups of OA synovial membranes. A significantly increased proportion of synovial membranes containing detritus showed the presence of fibrin compared with the other OA

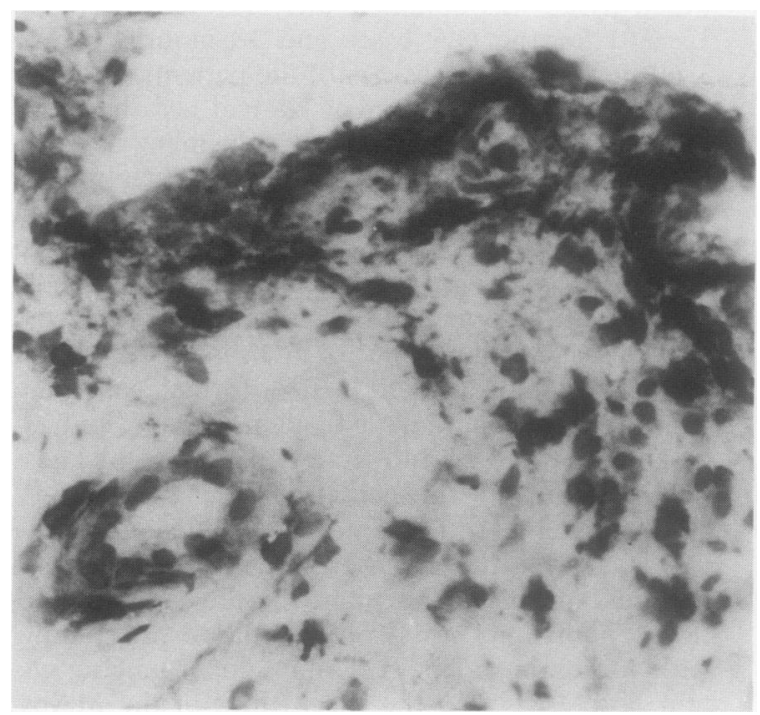

Fig. 1 Synovial membrane in $O A$ showing labelling of intimal cells with MAb 52 which marks the $H L A-D R$ molecule. Note there are also subintimal cells and perivascular cells labelled with this antibody. (Indirect immunoperoxidase, haematoxylin counterstain.)

Table 4 Distribution of cells marked with different monoclonal antibodies and the number of synovial membranes showing the presence of labelled cells at a particular site*

\begin{tabular}{|c|c|c|c|c|}
\hline \multirow{2}{*}{$\begin{array}{l}\text { Monoclonal } \\
\text { antibody } \\
\text { (target cell) }\end{array}$} & \multicolumn{4}{|l|}{ Site } \\
\hline & $\begin{array}{l}\text { Synovial } \\
\text { intimal } \\
\text { cell layer }\end{array}$ & $\begin{array}{l}\text { Subintimal } \\
\text { cells }\end{array}$ & $\begin{array}{l}\text { Deep diffuse } \\
\text { infiltrate }\end{array}$ & $\begin{array}{l}\text { Lymphoid } \\
\text { follicles }\end{array}$ \\
\hline 24 (macrophages) & 10 & 10 & 12 & 5 \\
\hline 44 (macrophages) & 17 & 16 & 18 & 5 \\
\hline OKM1 (macrophages) & 17 & 16 & 18 & 5 \\
\hline $10 \cdot 1$ (macrophages) & 17 & 17 & 19 & 5 \\
\hline OKT4 (T helper) & 10 & 10 & 12 & 5 \\
\hline OKT8 (T suppressor) & - & 10 & 12 & 7 \\
\hline Pan B (B lymphocytes) & - & 1 & 3 & 7 \\
\hline 52 (HLA-DR) & 20 & 18 & 18 & 5 \\
\hline 29 (granulocytes) & 11 & 5 & 5 & - \\
\hline
\end{tabular}

*Total number of samples $=20$. 
synovial membranes $\left(\chi^{2}=21 \cdot 2 ; p<0 \cdot 001\right)$. No other differences were found between OA synovial membranes in these different subgroups. There was no evidence of a specific relation between the presence of an inflammatory infiltrate in the synovial membrane and that of detritus or crystals.

\section{CELL POPULATIONS IN OA SYNOVIAL} MEM B R A N ES

Routine histological examination showed that over half the OA synovial membranes contained a

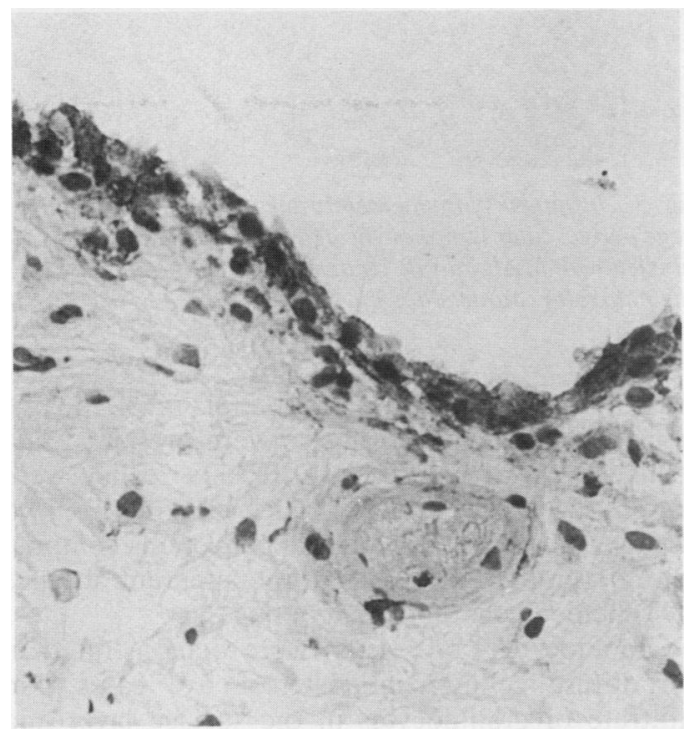

Fig. 2 Synovial membrane in OA showing labelling of intimal cells and some deeper cells with $M A b 44$, which marks the CR3 (C3bi) receptor. (Indirect immunoperoxidase, haematoxylin counterstain.) lymphoid infiltrate, that 17 showed lymphoid aggregates, and in seven of these lymphoid follicles (aggregates) were a well developed feature. Germinal centres were present in two of these cases. Frozen sections of fresh synovial membrane were available in 20 cases of $\mathrm{OA}$, and these were examined using monoclonal antibodies. Table 4 shows the overall distribution of cell types and numbers of samples showing the presence of labelling with particular monoclonal antibodies.

The synovial intimal cell layer showed staining with all four monocyte/macrophage markers, varying numbers of cells showing a positive reaction. These intimal cells were also HLA-DR positive using MAb 52 (Fig. 1). All but three of the synovial membranes showed staining of the intimal cell layer with MAb OKM1 and 44 (CR3 (C3bi) receptor) (Fig. 2). The pattern of staining was identical in 14 of the samples and differed only in the proportion of positively staining cells in the remaining three cases. The staining pattern with MAb $10 \cdot 1$ (high affinity Fc receptor) was similar to that obtained with the other two macrophage markers. In contrast, labelling with MAb 24 was absent from the intimal cell layer of 10 cases. In the remainder there was agreement with the results obtained with the other macrophage markers. The pattern of staining for HLA-DR in the intimal cell layer was in agreement with that found with OKM1, 44, and $10 \cdot 1$, rather than 24 . Half the synovial membranes showed the presence of OKT4+ $(10 / 20)$ and $29+(11 / 20)$ cells in the intimal cell layer, while the occasional OKT8+ cell was detected in the intimal cell layer in one sample and interpreted as an infiltrating lymphocyte. No Pan $\mathrm{B}+$ cells wire found in the intimal cell layer.

An infiltrate of macrophages was demonstrable immediately deep to the intimal cell layer in all but

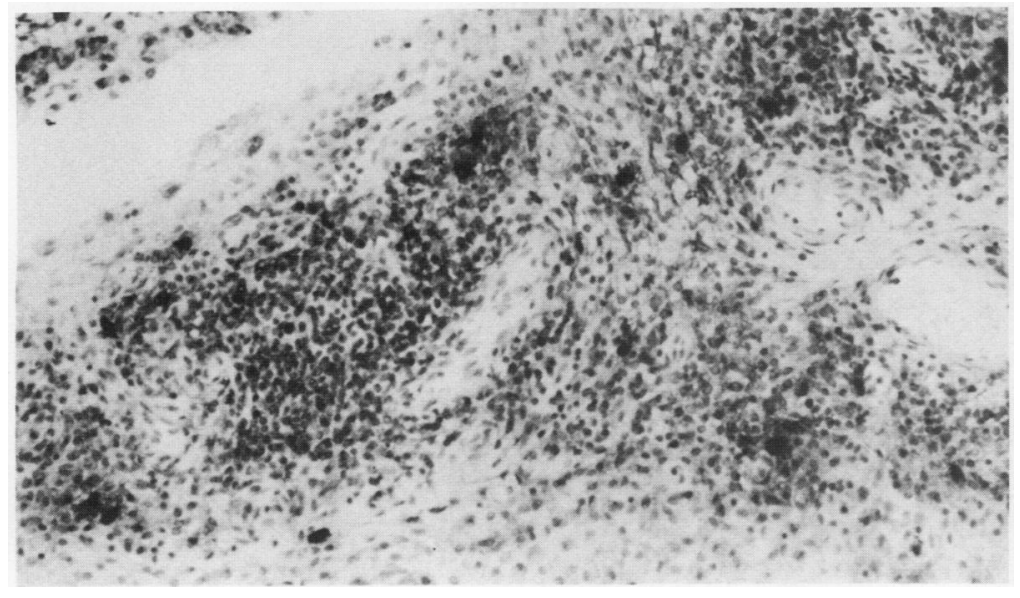

Fig. 3 Inflamed synovial membrane in $O A$ showing the presence of numerous MAb OKT4+ cells. (Indirect immunoperoxidase, haematoxylin counterstain.) 
four of the synovial membranes. There was complete agreement between the proportion of intimal cells and these deeper cells with respect to MAb 24 staining, 10 samples showing no staining at either location, nine showing the presence of some labelled cells, and one showing plentiful $24+$ cells. There was less agreement in the case of the other macrophage markers so that, for example, seven synovial membranes showed deep $44+$ cells in the absence of $44+$ intimal cells, while four cases had $44+$ intimal cells but no $44+$ deep cells. Similar discrepancies between intimal and subintimal populations were found with MAbs OKM1 and $10 \cdot 1$.

Half the OA synovial membranes showed the presence of OKT4+ and OKT8+ lymphocytes immediately beneath the intimal cell layer, but in only one sample were Pan B+ cells present in this location. All but two samples had HLA-DR+ cells deep to the surface (Fig. 1), and in half of the cases such cells were plentiful. The staining pattern with MAb 52 was similar to that seen with the macrophage markers; small numbers of perivascular HLA-DR+ macrophages were seen (Fig. 1).

The deeper diffuse synovial infiltrate had a composition similar to that in the immediately subsynovial tissue except for two cases in which there were no superficial $\mathrm{T}$ cells or macrophages, but these cells $(\mathrm{T} 4+, \mathrm{T} 8+, 10 \cdot 1+, 24+, \mathrm{OKM} 1+$, $44+)$ were plentiful in the deeper tissues. In both these cases lymphoid follicles were present , which contained $\mathrm{T} 4+, \mathrm{T} 8+, \mathrm{Pan} \mathrm{B}+$ cells as well as macrophages. Three further cases showed the presence of lymphoid follicles and in all of them B cells as well as T helpers, $\mathrm{T}$ suppressors (Figs 3, 4, and 5), and macrophages were present. The $T$ helper:sup-

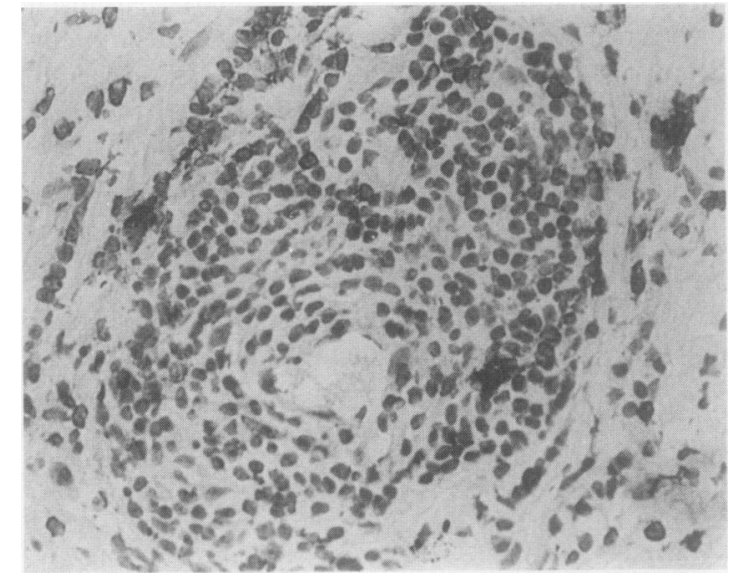

Fig. 5 Inflamed synovial membrane in $O A$ showing a large perivascular lymphocytic aggregate containing cells labelled with MAB Pan B. (Indirect immunoperoxidase, haematoxylin counterstain.)

pressor ratio varied between $1: 1$ and $2 \cdot 5: 1$ in the five cases where lymphoid follicles were present. Macrophages expressing HLA-DR $(52+$ cells) were present in the lymphoid follicles (Fig. 6). Two further cases showed lymphoid collections comprising T8+ and Pan B + cells in the apparent absence of $\mathrm{T}$ helper cells and macrophages.

Granulocytes (29+ cells) were demonstrated in the diffuse cellular infiltrate of five cases. An infiltrate of granulocytes in the surface layer and deeper tissues was present in those cases where other cells were plentiful ( $\mathrm{T}$ and $\mathrm{B}$ lymphocytes and macrophages) with or without formation of lym-

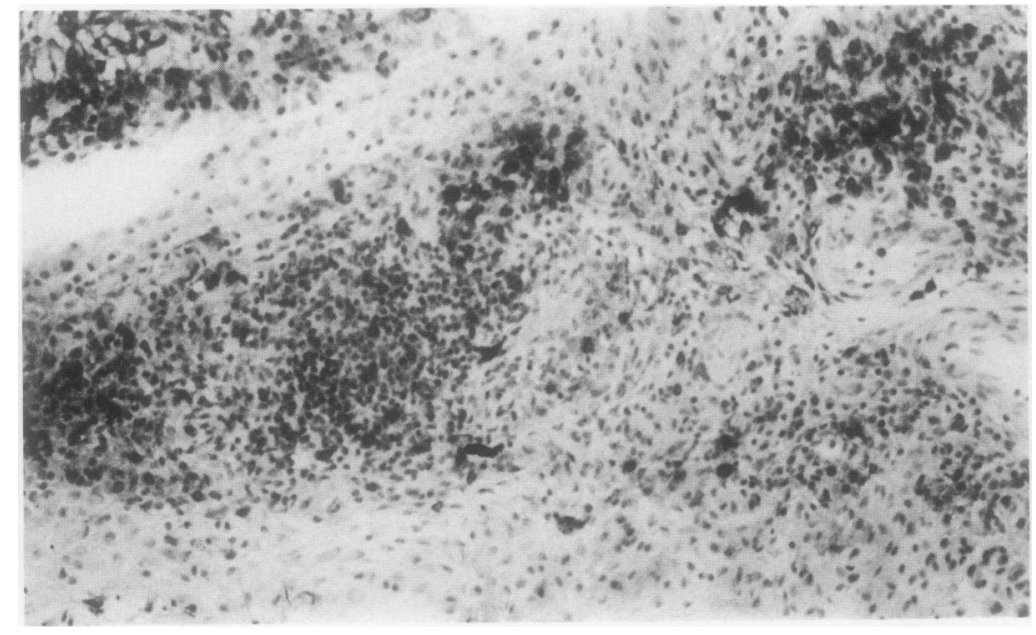

Fig. 4 Inflamed synovial membrane in $O A$, same field as Fig. 3 in an adjacent section, showing the presence of numerous $M A b O K T 8+$ cells. (Indirect immunoperoxidase, haematoxylin counterstain.) 


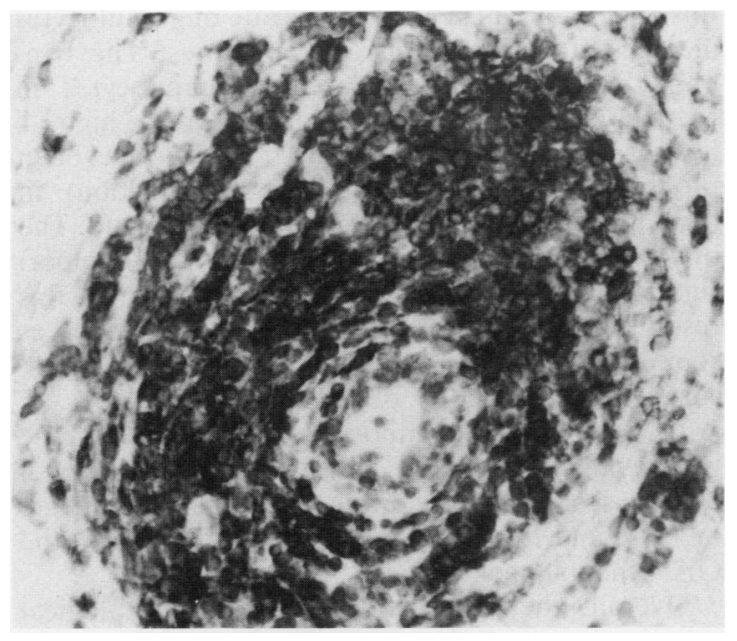

Fig. 6 Inflamed synovial membrane in $O A$, same field as Fig. 5 in an adjacent section, showing the presence of numerous cells labelled with MAb 52, an HLA-DR marker. (Indirect immunoperoxidase, haematoxylin counterstain.)

phoid follicles. In no case were granulocytes seen on their own.

CELL POPULATIONS IN MECHANICAL/

TRAUMATIC SYNOVIAL MEMBRANES

Examination of the small number of synovial samples from cases of MT joint damage available for monoclonal antibody studies showed a lack of inflammatory cell infiltration. Positive staining of the synovial surface intimal cells with OKT4 was seen in four out of the six cases, and cells at this site were also stained with macrophage monoclonal antibody markers. No granulocytes, $T$ suppressor cells, or B lymphocytes were seen in the intimal cell layer of these cases. Occasional OKT4t and OKT8+ cells were present in the subintimal and deeper synovial tissues in two of the MT samples. There were few macrophages and no B cells or granulocytes present. None of the MT cases studied with MAbs showed the presence of lymphoid follicles.

\section{Discussion}

Osteoarthritis is generally considered to be a noninflammatory condition and indeed is frequently referred to as degenerative joint disease. The older publications suggest that the synovial membrane is normal in appearance in osteoarthritis, showing no intimal cell hyperplasia or significant cellular infiltrate, though there may be fibrosis, increased vascularity, and fragments of cartilage present.
Recently, the presence of a low grade synovitis has been noted in osteoarthritis and some cases have been described in which the histological appearances were similar to those seen in rheumatoid arthritis and other chronic synovitides. ${ }^{311}$ The histological examination of synovial membrane from a series of clinically definite osteoarthritic joints in the present study confirms the presence of a group in which a significant inflammatory infiltrate is detectable, including the presence of lymphoid follicles. A previous comparison of osteoarthritic with rheumatoid synovial membranes has shown that a large number of histological features are shared by the two conditions, though some changes were more often found in the rheumatoid cases, particularly infiltrates, which included polymorphonuclear cells, lymphocytes, plasma cells, and histiocytes. ${ }^{12}$ The extent to which individual features were present was not examined in that study. A smaller semiquantitative study, however, showed that intimal cell hyperplasia, vascular changes, and leucocytic infiltration were present to a degree comparable with rheumatoid arthritis in some OA synovial membranes. ${ }^{13}$ The present results confirm previous observations that a proportion of synovial membranes from cases of osteoarthritis contain a significant inflammatory infiltrate with the presence of lymphoid follicles.

CPPD crystals have been found in the synovial fluid from osteoarthritic joints, as have apatite crystals. $^{14-16}$ The question of the relation between CPPD crystal deposition and osteoarthritis remains unanswered. It seems likely that phagocytosis of crystals by synovial macrophages may lead to the release of prostaglandins, neutral protease, and collagenase. ${ }^{14}$ CPPD crystals were observed in a small number of OA synovial membranes in the present study, but they were not related to the presence of any particular histological feature. Thus although it has been suggested that CPPD deposition is associated with accelerated $\mathrm{OA},{ }^{17}$ the relation remains unclear. Indeed, the present evidence suggests that crystal deposition is a secondary event and certainly not a cause of significant synovial inflammation.

The synovial membrane may show the incorporation of fragments of cartilage and bone from the joint surface in osteoarthritis. Comparison of those samples containing such detritus with other osteoarthritic synovial membranes, however, indicated that the only feature found more often in the presence of debris was deposition of fibrin at the synovial surface. Therefore, although there are possible theoretical reasons for the development of an inflammatory reaction in the osteoarthritic synovial membrane, these may be ruled out on the basis of a 
lack of association between cellular infiltrates and the presence of either crystals or detritus. It appears that there is a subgroup of osteoarthritis in which inflammation is a feature in the absence of such other potential stimuli-so called inflammatory osteoarthritis'. This identification of inflammation in OA in the definite absence of any apparent local provocative factors has not been made previously by a systematic investigation.

There have been no formal studies which address the question of the nature of the cellular infiltrate in the inflamed OA synovial membrane using monoclonal antibodies. Small numbers of OA synovial membranes have been used as 'non-inflammatory' controls in studies of rheumatoid arthritis. In one study around $28 \%$ of synovial cells were Ia positive in non-inflammatory joint disease compared with $62 \%$ in rheumatoid arthritis, ${ }^{7}$ a finding at variance with another report of $50-60 \%$ HLA-DR positive cells in osteoarthritis compared with $80-100 \%$ of such cells in rheumatoid disease. ${ }^{18}$ Cells expressing the HLA-DR molecule on their surfaces were present in both the intimal cell layer and the deep cellular infiltrate of the RA synovia studied. ${ }^{8}$ Macrophages have been shown to be confined to the intimal cell layer and to be present otherwise only as scattered deep cells in the osteoarthritic synovium. ${ }^{7} 810$ Perivascular lymphocyte collections in OA contain cells which are Ia or DR positive and mark with macrophage monoclonal antibodies. ${ }^{819}$

The present findings add to the previously recorded small number of observations in which monoclonal antibodies have been used to study OA synovial membranes-a total of 24 cases when all sources are combined. The intimal cell layer showed staining with the monocyte/macrophage markers $10 \cdot 1,24,44$, and OKM1, and in half the cases cells in this layer were also stained with OKT4 and 29, which are predominantly lymphocyte and granulocyte markers respectively, but which cross react with macrophages. There was good agreement between staining patterns using macrophage monoclonal antibodies which mark the same epitope. There was also good agreement between the proportions of macrophages showing the presence of high affinity $\mathrm{Fc}$ receptor $(10 \cdot 1)$ and $\mathrm{CR} 3(\mathrm{C} 3 \mathrm{bi})$ receptor $(44$, OKM1). The difference between the proportions of these cells and less mature macrophages, marked with 24 , has been reported previously ${ }^{21}$ and is confirmed in this study.

The presence of a marked deep inflammatory cell infiltrate in $\mathrm{OA}$ and its characterisation using monoclonal antibodies has not been described in detail elsewhere. Lymphoid follicles showed the presence of $\mathrm{T}$ helper, $\mathrm{T}$ suppressor, and $\mathrm{B}$ lymphocytes as well as macrophages, and those cases with this appearance also had an infiltrate of granulocytes in the surface layer and deeper tissues. The lymphoid follicles and perivascular lymphocytes in rheumatoid synovial membrane have a high $\mathrm{T}$ helper:suppressor cell ratio, ${ }^{623-25}$ and this has been proposed as evidence for a dysfunction in macrophage-lymphocyte immunoregulation. ${ }^{26}$ The present results fail to show a similarly high helper: suppressor ratio in OA. The significance of this result is difficult to assess at present, especially as some workers have not found a decrease in suppressor cells in all cases of rheumatoid arthritis. ${ }^{9} 23$ Although only small numbers of synovial membrane were available from MT joint involvement, none of these cases showed the diffuse lymphocytic infiltrate or lymphoid follicle formation seen in some of the OA synovial membranes.

Overall, the results of the routine histological examination and the monoclonal antibody study confirm the presence of a subgroup of osteoarthritis cases in which there is an inflammatory component with a lymphocyte infiltrate. In a proportion of $\mathrm{OA}$ synovial membranes the immunohistochemical results show a close similarity to those for rheumatoid arthritis in the cell types present and their distribution. The low helper:suppressor ratio is not incompatible with chronic synovitis and is sometimes seen in rheumatoid arthritis. A question arises as to whether inflammatory osteoarthritis cases are clinically unrecognised examples of rheumatoid arthritis or a similar chronic synovitis. Unfortunately, all histological studies of this sort are dependent on the reliability of clinical diagnosis. The patient records of each case in this series were reviewed by us and there was no evidence that any of the cases had rheumatoid or any other clinically recognised inflammatory joint disease. Only four of the osteoarthritic cases had five or more joints affected and none of these showed inflammatory changes on histology. It seems unlikely, therefore, that the inflammatory cases described here were clinically unrecognised examples of rheumatoid or similar arthritis. We believe that considerable further work is required to characterise inflammatory osteoarthritis both from the clinical and pathological points of view. We have, however, presented further evidence for this subgroup of osteoarthritis and have shown that this inflammation is likely to be unrelated to the presence of detritus or crystals.

The generosity of the Arthritis and Rheumatism Council for Research in providing financial support is gratefully acknowledged. The monoclonal antibodies were kindly donated by Dr Nancy Hogg, ICRF Laboratories, or obtained from Ortho and Dako Laboratories. 


\section{References}

1 Collins D H. The pathology of articular and spinal disease. London: Arnold, 1949: 74-115.

2 Roy S. Ultrastructure of synovial membrane of osteoarthritis. Ann Rheum Dis 1967; 26: 517-26.

3 Ito S, Bullough P G. Synovial and osseous inflammation in degenerative joint disease and rheumatoid arthritis of the hip. A histometric study. Transactions of the American Orthopedic Research Society 1979: 119.

4 Peyron J. Inflammation in osteoarthritis: review of its role and clinical picture, disease progress, subsets and pathophysiology. Semin Arthritis Rheum 1981; 11: 115-6.

5 Goldenberg D L, Cohen A S. Synovial membrane histopathology in the differential diagnosis of rheumatoid arthritis, gout, pseudogout, systemic lupus erythematosus, infections, arthritis and degenerative joint disease. Medicine (Baltimore) 1978; 57: 239-52.

6 Duke O, Panayi G S, Janossy G, Poulter L W. An immunohistological analysis of lymphocyte subpopulations and their microenvironment in the synovial membranes of patients with rheumatoid arthritis using monoclonal antibodies. Clin Exp Immunol 1982; 49: 22-30.

7 Burmester G R. Dimitriu-Bona A, Waters J J, Winchester R J. Identification of three major synovial lining cell populations by monoclonal antibodies directed to Ia antigens and antigens associated with monocytes/macrophages and fibroblasts. Scand J Immunol 1983; 17: 69-82.

8 Burmester G R, Locher P, Koch B, et al. The tissue architecture of synovial membranes in inflammatory and noninflammatory joint disease: the localization of the major synovial cell populations as detected by monoclonal reagents directed towards Ia and monocyte-macrophage antigens. Rheumatol Int 1983; 3: 173-81.

9 Koch B, Locher P, Burmester G R, Mohr W, Kalden J R. The tissue architecture of synovial membrane in inflammatory and non-inflammatory joint diseases: the localization of mononuclear cells as detected by monoclonal antibodies directed against T-lymphocyte subsets and natural killer cells. Rheumatol Int 1984; 4: 79-85.

10 Palmer D G, Selvendran Y, Allen C, Revell P A, Hogg N. Features of synovial membrane identificd with monoclonal antibodies. Clin Exp Immunol 1985; 59: 529-38.

11 Cooper N S, Soren A, McEwen C, Rosenberger J L. Diagnostic specificity of synovial lesions. Hum Pathol 1981; 12: 314-28.
12 Soren A. Ostcoarthritis-an arthritis? Z Rheumatol 1982; 41: 1-6.

13 Goldenberg D L. Egan M S, Cohen A S. Inflammatory synovitis in degenerative joint discasc. $J$ Rheumatol 1982: 9: 204-9.

14 Halverson P B, McCarty D J. Identification of hydroxyapatitc crystals in synovial fluid. Arthritis Rheum 1979: 22: 389-95.

15 Schumacher H R. Gordon G. Paul H, et al. Ostcoarthritis, crystal deposition, and inflammation. Semin Arthritis Rheum 1981; 11: 116-9.

16 Dieppe P A. Doherty M. MacFariene D J. Hutton C W. Bradfield J W, Watt $I$. Apatitc associated destructive arthritis. Br J Rheumatol 1984: 23: 84-91.

17 Hamilton E B D. Disease associated with CPPD deposition. Arthritis Rheum 1966; 19: 309-25.

18 Poulter L W, Duke O, Hobbs S, Janossy G, Panayi G. Histochemical discrimination of HLA-DR positive cell populations in the normal and arthritic synovial lining. Clin Exp Immunol 1982; 48: 381-8.

19 Hogg Nancy, Palmer D G, Revell P A. Mononuclear phagocytes of normal and rheumatoid synovial membrane identified by monoclonal antibodics. Immunology 1985; 56: 673-81.

$20 \mathrm{Hogg}$ N, Selvendran Y. An anti-human monocytc/macrophage monoclonal antibody reacting most strongly with macrophages in lymphoid organs. Cell Immunol 1985; 92: 247-53.

21 Palmer D G, Hogg N, Revell P A. Lymphocytes, polymorphonuclear leukocytes, macrophages and platelets in synovium involved by rhcumatoid arthritis. A study with monoclonal antibodics. Pathology 1986: 18: 431-7.

22 Breard J M, Reinherz E L, Kung P C. Goldstein G, Schlossman $S$ F. A monoclonal antibody reactive with human peripheral blood monocytes. J Immunol 1980; 24: 1943-8.

23 Forre O, Lea J T T, Dobloug J H, et al. In situ charactcrisation of mononuclear cells in rhcumatoid tissucs, using monoclonal antibodies. Scand J Immunol 1982; 16: 315-9.

24 Meijer C J L M. de Graaf-Reitsma C B. Lafeker G A J M. Cats A. In situ localisation of lymphocyte subsets in synovial membrancs of paticnts with rhcumatoid arthritis with monoclonal antibodies. J Rheumatol 1982: 9: 359-65.

25 Veys E M. Hermanns P. Schindler J. et al. Evaluation of T-cell subsets with monoclonal antibodics in paticnts with rheumatoid arthritis. J Rheumatol 1982; 9: 25-9.

26 Janossy G. Dukc O, Poulter L W. Panayi G. Bofill M. Goldstcin G. Rhcumatoid arthritis-a discasc of T lymphocytc/ macrophage immunorcgulation. Lancet 1981: ii: 839-42. 